\title{
REMEDIASI HASIL BELAJAR FISIKA DENGAN MEDIA ANIMASI PADA MATERI PEMANTULAN CAHAYA UNTUK SISWA KELAS VIII SMPN 2 JAWAI KABUPATEN SAMBAS KALIMANTAN BARAT
}

\author{
Wahyudi $^{1,2}$, Rima $^{1}$, Nurhayati $^{1}$ \\ ${ }^{1,2}$ Prodi Pendidikan Fisika IKIP PGRI Pontianak, Jl. Ampera No. 88, Pontianak \\ ${ }^{2}$ Email: wahyudi.kakap@gmail.com
}

\begin{abstract}
Abstrak
Penelitian ini bertujuan untuk mengetahui apakah remediasi hasil belajar fisika dengan media animasi dapat mempengaruhi hasil belajar siswa pada materi pemantulan cahaya untuk siswa kelas VIII SMPN 2 Jawai Kabupaten Sambas. Populasi dari penelitian ini adalah siswa kelas VIII SMPN 2 Jawai Kab.Sambas (Kalimantan Barat) yang terdiri dari kelas VIII A, VIII B, VIII C, dan VIII D. Sampel penelitian ini adalah kelas VIII A yang terdiri dari 27 siswa dengan nilai dibawah KKM yaitu $<75$, yang dipilih secara Cluster Random Sampling. Alat pengumpul data yang digunakan adalah tes hasil belajar fisika yang berbentuk uraian. Dari hasil penelitian diperoleh bahwa rata-rata hasil belajar siswa sebelum diberikan remediasi sebesar 52,63 dengan standar deviasinya 11,48 dan rata-rata hasil belajar siswa setelah diberikan remediasi sebesar 78,67 dengan standar deviasinya 6,84. Dari hasil analisis menggunakan uji t dengan $\alpha=5 \%$ diperoleh $t_{\text {hitng }}=16,12$ dan $t_{\text {tabel }}$

= 2,056 , karena $t_{\text {hitung }}$ tidak terletak pada daerah penerimaan $\mathrm{H}_{\mathrm{O}}$ (terima $\mathrm{H}_{\mathrm{O}}$ jika $-\mathrm{t}_{\text {tabel }}<$ $t_{\text {hitung }}<t_{\text {tabel }}$ ) sehingga dapat disimpulkan bahwa terdapat perbedaan yang signifikan sebesar 16,12. Selanjutnya dari perhitungan effect size diperoleh harga effect size sebesar 3,80 dengan kriteria tinggi. Hal ini menunjukan besar pengaruh remediasi hasil belajar siswa pada materi pemantulan cahaya dilihat dari hasil belajar siswa tergolong tinggi.
\end{abstract}

Kata Kunci: remediasi, hasil belajar, media animasi, pemantulan cahaya.

\section{PENDAHULUAN}

Pelajaran fisika merupakan salah satu pelajaran yang ada di sekolah, dan cabang dari ilmu pengetahuan alam (sains). Azhar (2012) mendefinisikan "sains adalah pengetahuan yang diperoleh melalui pembelajaran dan pembuktian atau pengetahuan yang melingkupi suatu kebenaran umum dari hukum-hukum alam". Selanjutnya ilmu pengetahuan alam (sains) juga didefinsikan oleh Widyaningsih (2012) sebagai ilmu yang mempelajari tentang segala sesuatu yang terdapat di alam, baik itu zat yang terkandung atau gejala yang terdapat di alam dan mempunyai kebenaran melalui metode ilmiah dengan ciri: objektif, empiris, sistimatis, universal dan verifikatif.

Tujuan dari pembelajaran fisika (sains) adalah membentuk kemampuan nalar pada diri siswa yang tercermin melalui kemampuan berfikir kritis, logis, sistematis dan memiliki sifat objektif, jujur, dan disiplin dalam menyelesaikan suatu permasalahan baik dalam bidang fisika, maupun bidang ilmu lain. Pencapaian tujuan pembelajaran fisika dapat dinilai dari keberhasilan siswa dalam memahami fisika dan memanfaatkan pemahaman ini untuk menyelesaikan persoalan fisika dalam kehidupan sehari-hari. Hal ini sejalan dengan tujuan pendidikan nasional (Undang Undang RI No 20 Tahun 2003 tentang Sistem Pendidikan Nasional) bertujuan untuk "mengembangkan potensi peserta didik agar menjadi manusia yang beriman dan bertakwa kepada Tuhan Yang Maha Esa, berakhlak mulia, sehat, berilmu, cakap, keratif, mandiri dan menjadi 
warga negara yang demokratis serta bertanggung jawab". Namun, tujuan tersebut dirasa sulit untuk tercapai mengingat masih rendahnya hasil belajar siswa pada mata pelajaran fisika. Hal ini terihat dari perolehan hasil ujian pada mata pelajaran IPA di SMPN 2 Jawai pada tahun 2011/2012 dengan rata-rata 5,72 dan pada tahun 2012/2013 dengan rata-rata 4,81 . Sejalan dengan penelitian Amalia (2009) mengungkapkan bahwa nilai fisika siswa rendah banyak disebabkan karena kurang teliti dalam menyelesaikan soalsoal yang menuntut konversi satuan, sulitnya siswa mangaplikasikan definisi/konsep kedalam cerita nyata, siswa tidak konsisten terhadap definisi/konsep yang dimaksud dalam soal, serta kurang cerdasnya siswa dalam menyikapi tipe soal yang mengecoh dan bentuk soal yang merugikan (karena berurutan dan saling berkaitan).

Salah satu materi dalam pelajaran IPA di sekolah menengah pertama yang masih dianggap sulit bagi siswa adalah materi pemantulan cahaya khususnya pada cermin. Pada materi pemantulan cahaya sangat berhubungan dengan kehidupan sehari-hari. Menurut Halliday dan Resnick (1984:639) pengalaman sehari-hari menunjukan bahwa bayangan maya memang "nyata" (ada) dan letaknya tertentu di "belakang" cermin, walaupun pada kenyataannya barangkali di belakang cermin tersebut adalah tembok. Pada materi pemantulan cahaya disini tidak hanya dijelaskan secara abstrak (tidak nyata) saja, tetapi dapat juga dijelaskan secara konkrit (nyata) dengan karakteristik dapat menjelaskan sinarsinar istimewa pada cermin dan dapat menjelaskan proses pembentukan bayangan pada cermin. Misalnya dalam proses pembentukan bayangan pada cermin datar sinar datang, sinar pantul, dan bayangan yang dihasilkan tidak dapat diamati secara langsung tanpa adanya bantuan demonstrasi yang dilakukan oleh guru.

Berdasarkan hasil pengamatan yang dilakukan di SMP Negeri 2 Jawai, diperoleh bahwa kesulitan belajar dalam pelajaran IPA di sekolah menengah pertama khususnya pada materi pemantulan pada cermin juga dialami oleh siswa kelas VIII SMPN 2 Jawai dan terbukti dengan banyaknya siswa yang mengalami kesulitan dalam menggambar sinar-sinar istimewa pada cermin, kesulitan dalam melukiskan bayangan pada cermin, kesulitan mengoperasikan rumus untuk menyelesaikan soal, dan siswa banyak keliru dalam menyikapi tipe soal yang mengecoh. Kesulitan siswa tersebut dapat dilihat dari banyaknya indikator yang belum tercapai melalui penyelesaian soal yang telah diberikan guru kepada siswa. Oleh sebab itu, dari banyaknya kesulitan yang dialami siswa dalam menyelesaikan soal berpengaruh terhadap hasil belajar yang diperoleh siswa. Sehingga belum mencapai ketuntasan standar minimum. Dari data yang diperoleh di SMPN 2 Jawai 2 tahun terahir berturut-turut, pada tahun ajaran 2011/2012 persentase ketuntasan pada hasil ulangan harian materi pemantulan cahaya adalah $40,54 \%$. Sedangkan pada tahun ajaran 2012/2013 persentase ketuntasan pada hasil ulangan harian materi pemantulan cahaya adalah $56,43 \%$. Dengan standar ketuntasan yang ingin dicapai secara klasikal adalah $75 \%$ dari seluruh siswa yang mendapat nilai $\geq 75$.

Upaya yang akan dilakukan untuk meningkatkan hasil belajar siswa adalah melalui perbaikan atau remediasi. Remediasi merupakan kegiatan pembelajaran yang diarahkan untuk mengatasi kesulitan peserta didik dengan cara mengubah, memperbaiki 
atau mempelajari kerangka berfikir siswa agar konsisten dengan kerangka berfikir ilmuwan (Sutrisno dalam Wahyudi, 2012). Sedangkan menurut penelitian Wahyudi (2012) mengungkapkan bahwa remediasi tidak ditujukan untuk memperbaiki miskonsepsi yang dimiliki siswa tetapi lebih diarahkan untuk memperbaiki nilai agar memenuhi standar ketuntasan belajar. Selain itu kegiatan perbaikan atau remediasi dalam proses pembelajaran pada dasarnya mencakup segala bantuan yang diberikan kepada siswa, baik yang lamban, kurang mengerti, siswa yang mengalami kesulitan maupun yang gagal dalam mencapai tujuan pengajaran yang telah ditentukan (Yusmin dalam Planantina, 2010:14). Dengan demikian perbaikan diarahkan pada pencapaian yang optimal sesuai dengan kemampuan masing-masing siswa melalui proses belajar mengajar dalam keseluruhan pribadi siswa.

Dari penjelasan di atas penelitian yang akan dilakukan adalah untuk memberikan perbaikan atau remediasi hasil belajar fisika yang dilakukan dalam bentuk pengajaran ulang dengan bantuan media animasi pada materi pemantulan cahaya. Dengan penggunaan media animasi diharapkan dapat membantu dari ketidakjelasan pemahaman siswa terhadap materi dapat dibantu dengan media sebagai perantara, misalnya dalam peningkatan pemahaman dari materi yang bersifat abstrak menjadi konkrit, serta kerumitan bahan pelajaran dapat disederhanakan dengan bantuan media animasi. Dimana dalam penyampaian materi pemantulan cahaya dengan media animasi termasuk dalam tahap demonstrasi. Didalamnya guru dapat mendemonstrasikan pembentukan bayangan pada masingmasing cermin. Sehingga bagi guru dapat memudahkan dalam penyampaian materi, sedangkan bagi siswa dapat membantu memudahkan dalam memahami konsep-konsep yang saling berhubungan, dan siswa tidak hanya membayangkan secara abstrak akan tetapi dapat melihat langsung konsepkonsep dalam materi pemantulan cahaya yang disampaikan oleh guru secara langsung. Berdasarkan penelitian Riza (2013) terdapat perbedaan rata-rata hasil belajar siswa setelah diajarkan menggunakan model Direct Instruction dengan batuan media animasi dengan effect size sebesar 0,54 dan tergolong sedang. Selanjutnya menurut penelitian Wahyudi \& Dinata (2013) menunjukan bahwa terdapat perbedaan antara hasil belajar siswa pada pembelajaran fisika menggunakan metode demonstrasi dengan media animasi yang lebih baik daripada pembelajaran fisika menggunakan metode konvensional, serta ditunjukan dengan aktivitas belajar siswa selama proses pembelajaran fisika menggunakan metode demonstrasi dengan media animasi tergolong tinggi dan lebih bersikap dan bertingkah laku positif selama pembelajaran berlangsung.

Sehingga dari penjelasan di atas, dengan penggunaan bantuan media animasi dalam kegiatan remediasi dirasakan cocok untuk memperbaiki hasil belajar siswa hingga mencapai standar ketuntasan yang telah ditentukan.

\section{METODE}

Metode penelitian yang digunakan dalam penelitian ini adalah metode eksperimen dengan bentuk penelitian pre-eksperimental design. Dikatakan pre-eksperimental design, karena desain yang digunakan belum merupakan eksperimen sungguh-sungguh dan masih terdapat variabel luar yang ikut berpengaruh terhadap terbentuknya variabel terikat (Sugiyono, 2011:109). 
Rancangan penelitian yang digunakan adalah One Group Pretest-Posttest Design (Sugiyono, 2011:110). Dimana sekelompok subjek dikenai perlakuan untuk jangka waktu tertentu, kemudian dilakukan pengukuran. Pengukuran dilakukan sebelum dan sesudah perlakuan diberikan dan pengaruh perlakuan diukur dari perbedaan antara perlakuan awal $\left(\mathrm{T}_{1}\right)$ dan pengukuran akhir $\left(\mathrm{T}_{2}\right)$.

Polpulasi dalam penelitian ini adalah seluruh siswa kelas VIII SMPN 2 Jawai Kabupaten Sambas, Kalimantan Barat, yang terdiri dari empat kelas. Berdasarkan data hasil rata-rata nilai ulangan fisika pada materi pemantulan cahaya, bahwa keempat kelas tersebut memiliki kemampuan rata-rata yang sama. Sampel diambil satu kelas dari populasi berjumlah empat kelas dengan teknik cluster random sampling, yaitu digunakan apabila populasi tidak berbentuk individu melainkan terdiri dari kelompok-kelompok individu yang dipilih secara acak. Terpilihlah kelas VIII A sebagai kelas eksperimen yang berjumlah 27 siswa.

Sesuai dengan tujuan penelitian yang ingin dicapai yaitu untuk mengetahui hasil belajar siswa setelah diajarkan menggunakan media animasi, maka teknik pengumpul data yang digunakan dalam penelitian adalah teknik pengukuran. Instrumen dalam penelitian ini terdiri dari dua yaitu instrumen pembelajaran dan instrumen pengumpul data. Instrumen pembelajaran terdiri dari silabus, RPP, dan LKS, sedangkan instrumen pengumpul data dibuat dan disesuaikan dengan teknik pengumpul data yakni soal tes hasil belajar yang berupa tes uraian.

Instrumen pengumpul data berupa soal tes uraian dengan menggunakan validitas isi oleh tiga orang validator dan hasil validitas isi tersebut menunjukkan bahwa instrumen pengumpul data tersebut dinyatakan layak digunaka. Selanjutnya, soal tes uraian divalidasi secara empiris dengan melakukan uji coba terhadap soal tes uraian tersebut. Setelah diuji cobakan selanjutnya dilakukan perhitungan validitas empiris (Arikunto, 2006:170) dan reliabilitas (Arikunto, 2006:196) soal tes uraian. Soal yang dipilih dari hasil uji coba menunjukkan kriteria yang valid, Soal akhir yang digunakan berjumlah 9 soal dengan kriteria reliabilitas termasuk kategori sedang $(0,597)$.

Analisis data yang digunakan untuk mendeskripsikan data hasil belajar dilakukan menggunakan statistik deskriptif yang meliputi rerata, nilai maksimum, nilai minimum, standar deviasi dan varians. Analisis data yang digunakan untuk membandingkan (komparatif) hasil belajar siswa sebelum diremediasi dengan media animasi dan setelah diremediasi dengan media animasi, digunakan statistik inferensial yang diawai dengan uji normalitas dan uji homogenitas data. Uji normalitas data dilakukan menggunakan uji chi kuadrat sedangkan uji homogenitas data dilakukan menggunakan uji barlett. Berdasarkan perhitungan uji normalitas dan uji homogenitas diperoleh informasi bahwa data pretest dan data postest berdistribusi normal dan bersifat homogen sehingga statistik inferensial yang digunakan yaitu uji-t satu sampel.

\section{HASIL DAN PEMBAHASAN Deskripsi Data}

\section{Hasil Tes Awal (Sebelum Remediasi) \\ Tes awal dilakukan sebelum} diberikan remediasi dengan media animasi. Rekapitulasi dari nilai tes awal pada siswa kelas VIII SMPN 2 Jawai pada materi pemantulan cahaya 
ditampilkan pada Tabel 1 sebagai berikut.

Tabel 1. Deskripsi Data Hasil Tes Awal Siswa

\begin{tabular}{clc}
\hline No. & \multicolumn{1}{c}{ Deskripsi Data } & Nilai \\
\hline \hline 1. & Nilai Minimum & 30,00 \\
2. & Nilai Maksimum & 71,00 \\
3. & Nilai Rata-rata & 52,63 \\
4. & Varians Data & 131,78 \\
5. & Standar Deviasi & 11,48 \\
6. & \% Ketuntasan & $0,00 \%$ \\
\hline
\end{tabular}

Pada Tabel 1 diketahui bahwa nilai minimum atau nilai terendah siswa adalah 30, sedangkan nilai maksimum atau nilai tertinggi siswa adalah 71 . Hasil pretest siswa menunjukan bahwa dari 27 siswa atau $0 \%$ siswa memperoleh nilai diatas 75 dan ditunjukan dengan hasil belajar siswa masih sangat rendah dengan rata-rata 52,63. Jika dilihat dari rata-rata hasi belajar siswa, maka besarnya varians data sebesar 131,78 dengan standar deviasi 11,48.

2. Hasil Tes Akhir (Setelah Remediasi) Setelah dilakukan tes awal atau pretest, kelas eksperimen ini diberikan perlakuan berupa pengajaran dengan media animasi, kemudian diberikan tes akhir atau posttest. Rekapitulasi dari nilai tes akhir pada siswa kelas VIII SMPN 2 Jawai pada materi pemantulan cahaya ditampilkan pada Tabel 2 sebagai berikut.

Tabel 2. Deskripsi Data Hasil Tes Akhir Siswa

\begin{tabular}{clc}
\hline No. & \multicolumn{1}{c}{ Deskripsi Data } & Nilai \\
\hline \hline 1. & Nilai Minimum & 65,00 \\
2. & Nilai Maksimum & 90,00 \\
3. & Nilai Rata-rata & 78,67 \\
4. & Varians Data & 46,85 \\
5. & Standar Deviasi & 6,84 \\
6. & \% Ketuntasan & $81,48 \%$ \\
\hline
\end{tabular}

Pada Tabel 2 diketahui bahwa nilai minimum atau nilai terendah siswa adalah 65, sedangkan nilai maksimum atau nilai tertinggi siswa adalah 90 . Hasil posttest siswa menunjukan bahwa dari 27 siswa atau $81,48 \%$ siswa memperoleh nilai diatas 75 dan ditunjukan dengan hasil belajar siswa tergolong sedang dengan rata-rata 78,67. Jika dilihat dari rata-rata hasi belajar siswa, maka besarnya varians data sebesar 46,85 dengan standar deviasi 6,84.

3. Perbandingan Hasil Tes Sebelum dan Setelah Remediasi

Adapun perbandingan sebelum dan setelah remediasi hasil belajar siswa dapat disajikan pada Gambar 1 diagram batang berikut: 


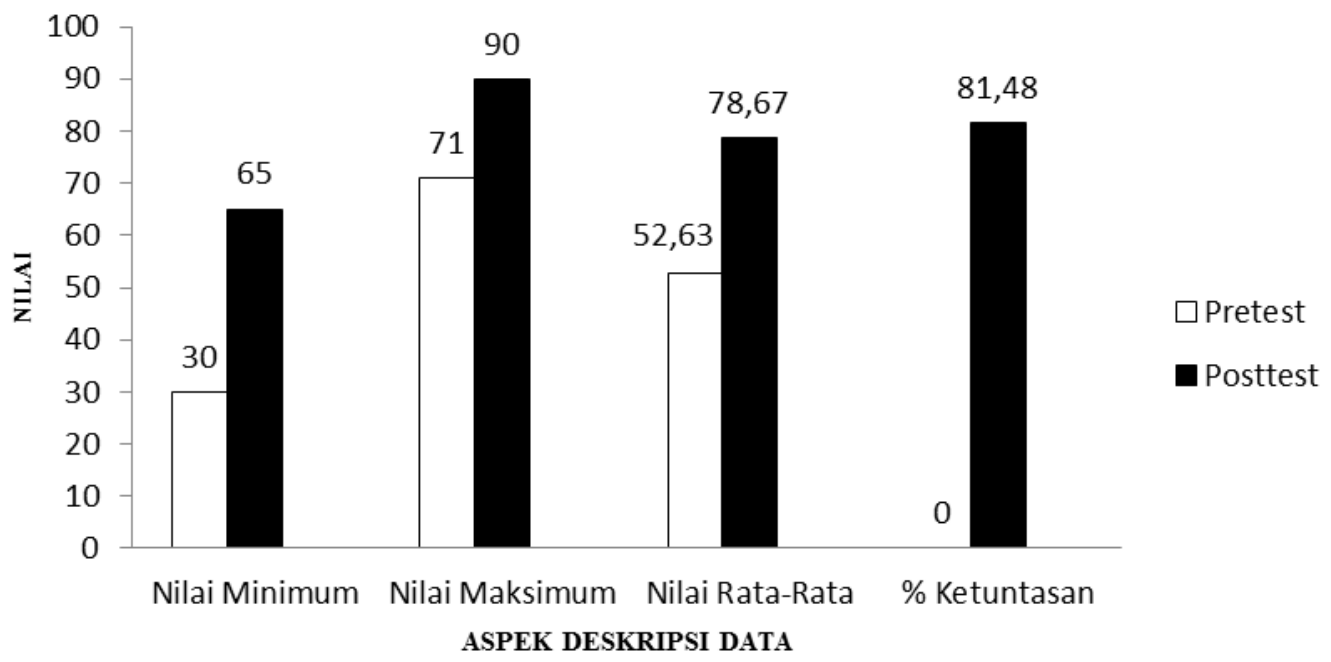

Gambar 1. Digram Batang Perbandingan Data hasil Tes awal dan Tes Akhir Siswa

Dari Gambar 1 diketahui bahwa perbandingan sebelum dan setelah remediasi hasil belajar siswa dengan media animasi dilihat dari nilai minimum atau nilai terendah dengan selisih nilai pretest (30) dan posttest (65) sebesar 35, sedangkan nilai maksimum atau nilai tertinggi dengan selisih nilai pretest (71) dan posttest (90) sebesar 19. Jika dilihat dari nilai rata-rata hasil pretest $(52,63)$ dan posttest $(78,67)$ selisih yang diperoleh sebesar 26,04 dengan ketuntasan yang diperoleh pada posttest $(81,48 \%)$ tergolong tinggi dibandingkan ketuntasan yang diperoleh pada pretest $(0 \%)$. Hal ini menunjukan adanya peningkatan hasil belajar siswa setelah diberikan perlakuan yaitu remediasi dengan bantuan media animasi.

\section{Pengujian Hipotesis}

Pengujian hipotesis dilakukan untuk mengetahui perbandingan ratarata hasil belajar siswa sebelum dan setelah dilakukan remediasi dengan media animasi. Pengujian hipotesis (komparatif) dilakukan dengan menggunakan uji t satu sampel. Adapun hipotesis dalam penelitian ini sebagai berikut.

1. Ho (hipotesis nol): Tidak terdapat perbedaan yang signifikan terhadap rata-rata hasil belajar siswa sebelum dan setelah diberikan remediasi dengan media animasi pada materi pemantulan cahaya untuk siswa kelas VIII SMPN 2 Jawai Kabupaten Sambas.

2. Ha (hipotesis alternatif): Terdapat perbedaan yang signifikan terhadap rata-rata hasil belajar siswa sebelum dan setelah diberikan remediasi dengan media animasi pada materi pemantulan cahaya untuk siswa kelas VIII SMPN 2 Jawai Kabupaten Sambas.

Data hasil uji hipotesis dapat dilihat pada Tabel 3 sebagai berikut.

Tabel 3. Data Hasil Uji t

\begin{tabular}{ccl}
\hline$t_{\text {Hitung }}$ & $t_{\text {Tabel }}$ & \multicolumn{2}{c}{ Keterangan } \\
\hline \hline \multirow{2}{*}{16,12} & 2,056 & $\begin{array}{l}\text { Terdapat perbedaan yang signifikan terhadap rata- } \\
\text { rata hasil belajar siswa sebelum dan setelah } \\
\text { diberikan remediasi dengan media animasi }\end{array}$
\end{tabular}


Berdasarkan Tabel 3 diperoleh $t_{\text {hitung }}(16,12)$ lebih besar dari pada $t_{\text {Tabel }}(2,056)$. Untuk derajat kebebasan $(\mathrm{db})=\mathrm{n}-1=27-1=26$ dan taraf sigifikansi $(\alpha)$ sebesar 0,05 , maka dapat disimpulkan bahwa terdapat perbedaan yang signifikan terhadap rata-rata hasil belajar siswa sebelum dan setelah diberikan remediasi dengan media animasi pada materi pemantulan cahaya untuk siswa kelas VIII SMPN 2 Jawai Kabupaten Sambas.

\section{Pembahasan}

Dalam penelitian ini bertujuan untuk mengetahui apakah remediasi dengan media animasi dapat mempengaruhi hasil belajar siswa pada materi pemantulan cahaya. Ada beberapa hal yang dibahas berkaitan dengan permasalahan penelitian dan mengacu pada hasil analisis data siswa.

1. Hasil Tes Sebelum Remediasi

Hasil data menunjukan bahwa sebelum remediasi rata-rata hasil tes siswa yang diperoleh tergolong rendah. Rendahnya hasil tes sebelum remediasi ini disebabkan karena kurangnya penguasaan siswa terhadap materi yang disampaikan guru dan juga sebagian siswa beranggapan bahwa materi pemantulan cahaya tergolong sulit. Dimana siswa tidak hanya bisa memahami konsep, tetapi siswa juga harus bisa menerapkan rumus kedalam contoh soal. Sehingga banyak indikator yang masih belum tercapai dan masih banyak siswa yang memperoleh hasil belajar dibawah Kriteria Ketuntasan Minimum (KKM) yaitu $<75$.

Dalam mempelajari materi pemantulan cahaya tidak hanya dijelaskan secara abstrak (tidak nyata) saja, tetapi dapat juga dijelaskan secara konkrit (nyata). Dengan karakteristik materi dapat menjelaskan sinar-sinar istimewa pada cermin dan dapat menjelaskan proses pembentukan bayangan pada cermin. Misalnya dalam proses pembentukan bayangan pada cermin datar, jalannya sinar datang masuk melalui cermin tidak dapat diamati secara langsung tanpa adanya bantuan demonstrasi yang dilakukan oleh guru. Hal tersebut menyebabkan siswa sulit untuk memahami materi yang disampaikan oleh guru, sehingga banyak siswa memperoleh nilai dibawah standar ketuntasan minimum.

\section{Hasil Tes Setelah Remediasi}

Setelah diberikan perlakuan menggunakan media animasi, maka akan dilakukan tes kembali yaitu tes akhir (posttest). Hasil data tes akhir menunjukan bahwa setelah remediasi, rata-rata yang diperoleh tergolong sedang dengan ketuntasan klasikal yang diperoleh tergolong tinggi sebesar $81,48 \%$ dari seluruh siswa yang mendapat nilai $\geq 75$. Dilihat dari hasil belajar siswa dengan bantuan media animasi yang digunakan, maka media animasi bertujuan untuk meningkatkan motivasi siswa, merangsang siswa mengingat apa yang sudah dipelajari, mengaktifkan siswa dalam memberikan tanggapan dan umpan balik, serta mendorong siswa untuk melakukan praktik-praktik yang benar (Hamdani, 2011:73). Selanjutnya media animasi juga berfungsi dapat mengatasi kemampuan siswa yang berbeda, dapat menampilkan objek yang terlalu kecil dan dapat menyajikan informasi secara konsisten (Rohmadi dkk, 2013:101). Sehingga dapat disimpulkan bahwa dengan menggunakan media animasi dapat meningkatkan hasil belajar siswa dengan selisih hasil tes awal (pretest) dan hasil tes akhir (posttest) yang diperoleh sebesar 26,04.

Jika dikaitkan dengan model pembelajaran yang diterapkan, maka dalam penyampaian materi pemantulan cahaya dengan media animasi termasuk 
dalam tahap demonstrasi. Dimana guru mendemonstrasikan pembentukan bayangan pada masing-masing cermin. Sehingga bagi guru dapat memudahkan dalam penyampaian materi, sedangkan bagi siswa dapat membantu memudahkan dalam memahami konsepkonsep yang saling berhubungan, dan siswa tidak hanya membayangkan secara abstrak akan tetapi dapat melihat langsung konsep-konsep dalam materi pemantulan cahaya yang disampaikan oleh guru secara langsung. Sehingga siswa dapat meminimalisir kesalahan penafsiran yang mungkin terjadi pada saat proses belajar mengajar. Hal ini sejalan dengan penelitian Wahyudi dan Dinata (2013) yang menunjukan bahwa terdapat perbedaan antara hasil belajar siswa pada pembelajaran fisika menggunakan metode demonstrasi dengan media animasi yang lebih baik daripada pembelajaran fisika menggunakan metode konvensional, serta ditunjukan dengan aktivitas belajar siswa selama proses pembelajaran fisika menggunakan metode demonstrasi dengan media animasi tergolong tinggi dan lebih bersikap dan bertingkah laku positif selama pembelajaran berlangsung. Kemudian hasil penelitian Some dkk (2013) menunjukan bahwa penggunaan macromedia flash sangat berpengaruh terhadap minat belajar siswa.

Dengan demikian, remediasi hasil belajar siswa dengan media animasi pada materi pemantulan cahaya efektif dapat meningkatkan hasil belajar siswa dengan mendorong siswa untuk berfikir lebih luas sehingga mereka dapat membangun pengetahuan mereka sendiri, mereka bisa mengemukakan pendapat, mengambil kesimpulan dan dapat melihat langsung proses terjadinya. Sehingga hal ini sejalan dengan teori belajar menurut Gestalt (Mahmud, 2012:88), dimana "belajar adalah suatu proses rentetan penemuan dengan bantuan pengalamanpengalaman yang sudah ada". Pengalaman yang dimaksudkan disini adalah dimana siswa yang sebelumnya diajarkan dengan metode konvensional (ceramah) akan dijarkan kembali pada materi yang sama tetapi dengan bantuan media animasi. Sehingga dengan pengalaman ini akan mempermudah siswa untuk mengingat kembali dan mempelajari materi yang telah disampaikan oleh guru.

Dilihat dari perbandingan hasil belajar siswa, didasarkan pada skor tes awal (pretest) dan skor tes akhir (posttest) siswa. Hal itu dilakukan untuk menguji hipotesis apakah terdapat perbedaan yang signifikan terhadap rata-rata hasil belajar siswa sebelum dan setelah diberikan remediasi dengan media animasi pada materi pemantulan cahaya. Dari hasil analisis statistik menggunakan uji t menunjukan bahwa terdapat perbedaan yang signifikan hasil belajar siswa antara sebelum dan sesudah dilakukan remediasi. Terjadinya perbedaan hasil belajar siswa dikarenakan remediasi dengan media animasi mendorong siswa untuk berfikir lebih luas sehingga mereka dapat membangun pengetahuan mereka sendiri, mereka bisa mengemukakan pendapat, mengambil kesimpulan dan dapat melihat langsung proses terjadinya. Sementara itu dari perhitungan effect size diperoleh harga effect size sebesar 3,80. Sehingga besar pengaruh remediasi hasil belajar siswa dengan media animasi tergolong tinggi. Hal ini sejalan dengan penelitian Riza (2013) terdapat perbedaan rata-rata hasil belajar siswa setelah diajarkan menggunakan model Direct Instruction dengan batuan media animasi dengan effect size sebesar 0,54 dan tergolong sedang. Sedangkan menurut penelitian Sakti (2013) media animasi dalam 
model pembelajaran langsung (direct instruction) berpengaruh terhadap minat belajar dan pemahaman konsep fisika siswa di SMA.

\section{SIMPULAN}

Berdasarkan analisis data yang diperoleh maka remediasi hasil belajar fisika dengan media animasi dapat mempengaruhi hasil belajar siswa pada materi pemantulan cahaya untuk siswa kelas VIII SMPN 2 Jawai Kabupaten Sambas. Beberapa rincian kesimpulan penelitian ini adalah sebagai berikut:

1. Rata-rata hasil belajar siswa sebelum diberikan remediasi dengan media animasi pada materi pemantulan cahaya tergolong cukup yaitu 52,63 dengan standar deviasi 11,48.

2. Rata-rata hasil belajar siswa setelah diberikan remediasi dengan media animasi pada materi pemantulan cahaya tergolong baik yaitu 78,67 dengan standar deviasi 6,84.

3. Terdapat perbedaan yang signifikan terhadap rata-rata hasil belajar siswa sebelum dan setelah diberikan remediasi dengan media animasi pada materi pemantulan cahaya. Hasil belajar siswa setelah diberikan remediasi dengan media animasi lebih baik dibandingkan hasil belajar siswa sebelum diberikan remediasi dengan media animasi.

4. Besar pengaruh remediasi hasil belajar fisika dengan media animasi pada materi pemantulan cahaya tergolong tinggi dengan effect size sebesar 3,80.

\section{Daftar Rujukan}

Amalia, \& Viridi, S. 2009. Analisis Penyebab Rendahnya Nilai Fisika pada Materi Gerak Melingkar di SMA Negeri 6 Bandung. Jurnal Pengajaran Fisika Sekolah Menegah,Vol.1, No.3, hal.1-6.
Arikunto, S. 2006. Prosedur Penelitian Suatu Pendekatan Praktik. Jakarta: Rineka Cipta.

Azhar. 2012. Pengertian dan seluk Beluk Sains. [Online]. Tersedia: http://

pusatbahasaalazhar.wordpress.co $\underline{m}$ [12 Agustus 2013].

Wahyudi, \& Dinata, W. A. 2013. Pembelajaran Fisika Menggunakan Metode Demonstrasi dengan Media Animasi pada Materi Konsep Zat di Kelas VII SMPN 4 Pontianak. Pontianak. Jurnal Pendidikan Informatika dan Sains, Vol.2, No.2, hal.187-200.

Halliday, R. 1984. Fisika JILID 2 Edisi ketiga. Bandung: PT. Gelora Aksara Pratama.

Hamdani. 2011. Strategi belajar mengajar. Bandung: CV Pustaka Setia.

Mahmud. 2012. Psikologi Pendidikan. Bandung: CV Pustaka Setia.

Planantina, D. 2010. Remediasi Melalui Latihan Terbimbing pada Materi Sistem Persamaan linear tiga variabel. Pontianak: STKIP-PGRI Pontianak. (Skripsi tidak diterbitkan).

Riza, M. 2013. Penerapan Model Pembelajaran Direct Instruction dengan Bantuan Media Animasi pada Materi Pemantulan Cahaya di Kelas X SMA N 1 Ketapang. Pontianak : $\quad$ STKIP-PGRI Pontianak. (Skripsi tidak diterbitkan).

Rohmadi, M., Aliwanto, \& Lahir, M. 2013. Biografi Samion H. AR (Inspirator dan Motivator Pendidikan Di Kalimantan Barat). Surakarta: Yuma Pustaka.

Sakti, I. 2013. Pengaruh Media Animasi Fisika dalam Model Pembelajaran Langsung (Direct Instruction) Terhadap Minat 
Belajar dan Pemahaman Konsep Fisika Siswa di SMA Negeri Kota Bengkulu. [Online]. Tersedia: http://jurnal.fmipa.unila.ac.id. [7 Juli 2014].

Some, I. M., Arbie. A., \& Payu. C. S. (2013). Pengaruh Penggunaan Macromedia Flash Terhadap Minat Belajar Siswa pada Mata Pelajaran Fisika. [Online]. Tersedia: http://kim.ung.ac.id. [4 September 2014].

Sugiyono. (2011). Metode Penelitian Pendidikan (Pendekatan Kuantitatif, Kualitatif, dan $R \& D)$. Bandung: Alfabeta.

Wahyudi. 2012. Implementasi Program Remediasi pada Materi Fisika di SMP Negeri 08 Pontianak. Jurnal Edukasi, Vol.8, No.2, hal.172179.

Widyaningsih, S. (2012). Definisi Ilmu Pengetahuan Alam (IPA). [Online]. Tersedia: http://sriwahyuwidyaningsih.blogs pot.com [12 Agustus 2013]. 